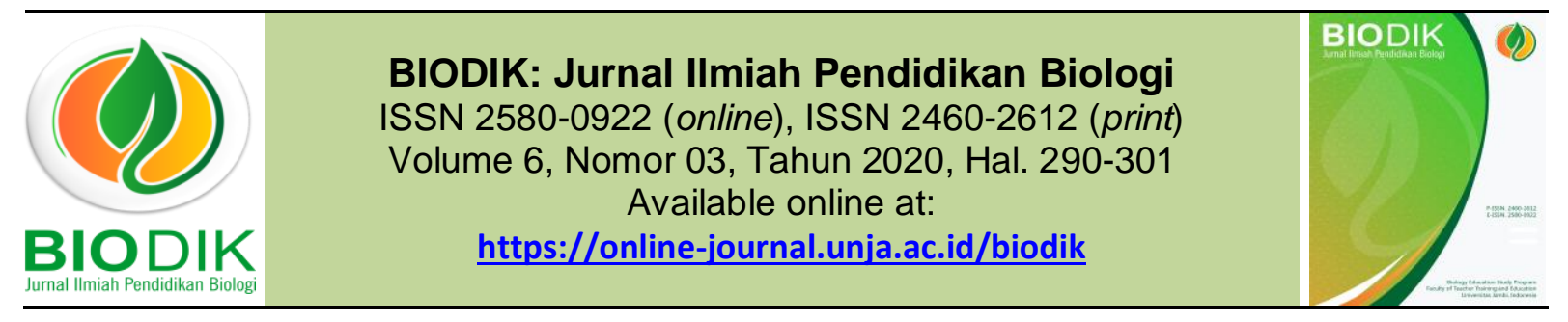

Research Article

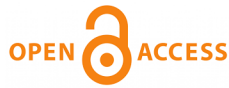

\title{
Analisis Kegiatan Praktikum Biologi SMA Materi Sistem Pernapasan Manusia
}

\author{
(Analysis of Biology Practical Laboratory Activity For Senior High School in Human \\ Respiratory System Student Worksheets)
}

\author{
Meirin Dwiningtyas Putri*, Sri Anggraeni, Bambang Supriatno \\ Universitas Pendidikan Indonesia, Bandung \\ Jalan Dr. Setiabudi No. 229, Bandung 40415, Indonesia \\ *Corresponding Author: meirindwi@gmail.com
}

\begin{tabular}{ll}
\hline Informasi Artikel & ABSTRACT \\
\hline Submit: 02-06-2020 & This study aims to provide an overview of the design of the respiratory \\
Diterima: $30-08-2020$ & system practicum used in SMA / MA Tasikmalaya and the subject of \\
Dipublikasikan: 04-09-2020 & this research is the Student Worksheet (LKS) of Human Respiratory \\
& System Practicum used in schools. Samples taken in this study were \\
& 6 LKS samples. The sampling technique by purposive sampling. This \\
& study uses instruments developed by the Lecturer TEAM and \\
& instruments based on the scoring table of the Diagram Vee \\
component that was adapted by Novak \& Gowin. Based on the \\
instruments developed by the Lecturer TEAM, it shows that the results \\
of the analysis of LKS practicum activities on human respiratory \\
system material still found problems in terms of 1) conceptual, not in \\
accordance with the demands of Basic Curriculum Competence 2) \\
practical, the title / goal is not in accordance with the work steps and \\
difficult to execute and not relevant to the object / phenomenon that \\
appears 3) the construction of knowledge, the question has not led to \\
the facts that arise, is not related to the interpretation of the data and \\
the conclusions that are built do not describe the title / purpose of the \\
practicum. Whereas based on the analysis results of the scoring \\
instrument Diagram Vee shows that the components of focus \\
questions, objects / events, concepts / theories / principles, \\
transformation notes, and knowledge claims have not yet reached the \\
maximum score so that the outstanding Practicum Worksheet has not \\
supported Diagram Vee components to the maximum so it needs to \\
be improved. \\
Keywords Student Worksheet, Human Respiratory System, Diagram \\
Vee
\end{tabular}


sesuai dengan tuntutan Kompetensi Dasar kurikulum 2) praktikal, judul/tujuan belum sesuai langkah kerja dan sulit dieksekusi serta tidak relevan dengan objek/fenomena yang muncul 3) kontruksi pengetahuan, pertanyaan belum mengarahkan pada fakta yang muncul, tidak dihubungkan dengan interpretasi data serta kesimpulan yang dibangun belum menggambarkan judul/tujuan praktikum. Sedangkan berdasarkan hasil analisis instrumen penskoran Diagram Vee menunjukkan bahwa komponen pertanyaan fokus, objek/peristiwa, konsep/teori/prinsip, catatan transformasi, dan klaim pengetahuan masih belum mencapai skor maksimal sehingga LKS Praktikum yang beredar belum menunjang komponen Diagram Vee dengan maksimal sehingga perlu ditingkatkan.

Katakunci: Lembar Kerja Siswa, Sistem Pernapasan Manusia,

Diagram Vee.

This BIODIK : Jurnal IImiah Pendidikan Biologi is licensed under a CC BY-NC-SA (Creative Commons Attribution-ShareAlike 4.0 International License)

\section{PENDAHULUAN}

Abad ke-21 merupakan abad globalisasi yang penuh tantangan. Tantangan abad 21 khususnya pembelajaran biologi memiliki peran sains bagi kehidupan masa depan menyiapkan siswa untuk mampu berpikir kritis, kreatif, kompetitif, mampu memecahkan masalah serta berani mengambil keputusan secara cepat dan tepat (Sudarisman, 2015). Pembelajaran biologi idealnya dikembangkan sesuai dengan hakikat belajar sains. Hakikat pembelajaran sains mengandung empat unsur yaitu: (1) proses (scientific process) meliputi aktivitas ilmiah siswa seperti mengamati, menganalisis, melakukan percobaan untuk menemukan sendiri, (2) produk (scientific products) berupa produk ilmiah berupa konsep materi yang dapat dicapai siswa setelah melakukan kegiatan proses ilmiah (3) sikap (scientific attitudes) berupa sikap ilmiah yang meliputi kejujuran, tanggungjawab, ketelitian, dan lain-lain serta (4) teknologi (Carin, 1997; Suryaningsih, 2017).

Kegiatan praktikum sangat penting dalam pembelajaran biologi karena (1) memberi pengalaman belajar secara nyata dan mengembangkan keterampilan dasar bekerja di laboratorium; (2) membantu siswa menghubungkan antara dua ranah pengetahuan yaitu objek atau fenomena yang teramati dan ranah gagasan atau ide; (3) melatih kemampuan kognitif, afektif dan psikomotorik dalam memahami suatu fenomena biologi; (4) menunjang materi ajar dalam memahami konsep yang sulit dan abstrak; serta (5) memberikan pengalaman yang nyata dalam usaha menciptakan pengalaman baru (Ulfa, 2016; Wahidah, et.al., 2018).

Untuk menunjang kegiatan praktikum dibutuhkan sebuah pedoman yang mengarahkan siswa untuk mengkontruksi pengetahuannya berdasarkan fenomena yang muncul. Permasalahan yang dipaparkan oleh Supriatno (2013) bahwa Lembar Kerja Siswa (LKS) yang beredar di lapangan memiliki permasalahan yaitu (1) tujuan praktikum lebih banyak menekankan aspek kognitif daripada psikomotor; (2) sebagian besar menggunakan pendekatan deduktif dengan model ekspositori; (3) prosedur praktikum meskipun rinci, beberapa diantaranya tidak terstruktur dan perintahnya membingungkan sehingga menimbulkan penafsiran ganda; serta (4) 
pemilihan materi tidak mempertimbangkan esensi kesesuian, kedalaman, dan kompleksitasnya.

Selaras dengan permasalahan Supriatno (2013) permasalahan lainnya dipaparkan oleh Asrianengsi et.al., (2018) bahwa sekolah menggunakan panduan praktikum LKS yang sudah ada belum sesuai dengan kurikulum 2013 sehingga hal ini merupakan salah satu masalah dalam pelaksanaan praktikum. Berdasarkan analisis penggunaan panduan praktikum LKS diperoleh sebagai berikut (1) tidak terdapat tata tertib; (2) belum menerapkan pendekatan atau stategi pembelajaran; (3) tujuan praktikum masih secara umum; (4) teori dasar masih sangat sedikit; (5) langkah kerja belum menekankan siswa untuk mencari dan menemukan jawaban sendiri serta belum dapat mengembangkan kemampuan berpikir sistematis, kritis, logis, dan analitis (6) terdapat pertanyaan pemahaman konsep biasa sehingga yang diperoleh hanya tingkat hafalan dan mengingat.

Permasalahan yang dipaparkan oleh Supriatno (2013) dan Asrianengsi, et.al., (2018) juga ditemukan oleh peneliti, yaitu LKS yang digunakan guru di sekolah tujuan praktikumnya tidak jelas, peristiwa dan fenomena dalam kegiatan praktikum tidak sesuai dengan konsep materi yang dipelajari. Selain itu pelaksanaan praktikum dalam LKS tidak sesuai dengan kompetensi dasar jenjang pendidikan yang diharapkan pada kurikulum. Materi sistem pernapasan yang dipelajari di SMA/MA merupakan materi ajar yang dapat dipelajari tetapi dianggap abstrak karena tidak dapat di visualisasikan secara nyata maka dituntut adanya kegiatan praktikum. Namun, peneliti masih menemukan ketidaksesuaian penerapan praktikum materi sistem pernapasan diantaranya (1) ketidaksesuaian judul/tujuan dengan prosedur praktikum sehingga belum mampu mengkontruksi pengetahuan siswa (2) tidak adanya pencatatan data sehingga siswa hanya mengamati yang berpengaruh terhadap penarikan kesimpulan kegiatan praktikum (3) pertanyaan yang terdapat dalam LKS belum dapat mengarah pada kegiatan praktikum yang dilakukan siswa (4) ketidaksesuaian kegiatan praktikum dengan kompetensi dasar dalam kurikulum. Berbagai permasalahan yang telah dipaparkan menjadi bahan masukan untuk memperbaiki Lembar Kerja Siswa (LKS) di masa yang akan datang. Lembar Kerja Siswa (LKS) praktikum hendaknya dapat membantu siswa untuk mengontruksi pengetahuannya serta mengembangkan kemampuan berpikir siswa. Maka dari itu sebagai patokan dalam penyusunan LKS yang mengarahkan pembelajaran praktikum bermakna dengan menggunakan Diagram Vee sebagai acuan. Diagram Vee merupakan sebuah alat yang dapat digunakan untuk membantu memecahkan masalah atau memahami prosedur (Novak dan Gowin, 1984) yang memiliki dua sisi yang saling mendukung yaitu sisi konseptual (berpikir) dan sisi metodologis (bekerja). Kedua sisi Diagram Vee menekankan dua aspek yang saling bergantung yaitu teori (thinking) dan praktik (doing). Bagian-bagian aspek Diagram Vee mempresentasikan teori kontruktivisme dalam memperoleh pengetahuan sehingga dapat membantu siswa untuk membangun struktur pengetahuannya dan meningkatkan prestasi belajar siswa (Huzaifah, et.al., 2017). 


\section{METODE PENELITIAN}

Metode penelitian yang digunakan adalah deskriptif kualitatif karena bertujuan untuk menggambarkan fenomena-fenomena yang ditemukan. Penelitian diupayakan dapat memberikan gambaran mengenai desain praktikum sistem pernapasan yang digunakan di SMA/MA Tasikmalaya. Sampel yang diambil dalam penelitian ini yaitu 6 sampel LKS SMA/MA. Teknik sampling dilakukan secara purposive sampling. Instrumen penelitian yang digunakan yaitu instrumen yang dikembangkan oleh TIM Dosen meliputi analisis konseptual, analisis praktikal dan analisis kontruksi pengetahuan serta instrumen berdasarkan tabel penskoran komponen Diagram Vee yang diadaptasi Novak dan Gowin (1984) yang terdiri dari lima komponen yaitu pertanyaan fokus (focus question), objek/peristiwa (objek/events), konsep/prinsip/teori (concepts/principles/theories), catatan/transformasi (records/transformtions), dan klaim pengetahuan (knowledge claim).

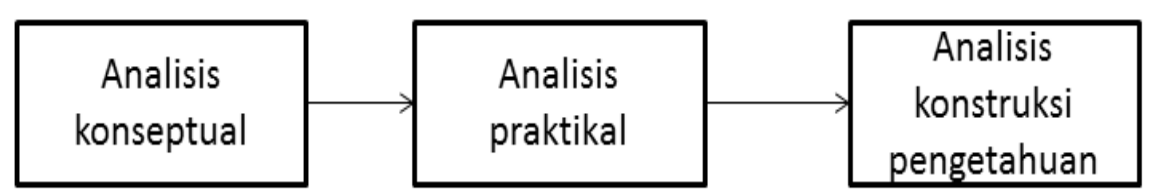

Gambar 1. Tahapan penelitian

\section{HASIL DAN PEMBAHASAN}

Analisis Konseptual LKS Sistem Pernapasan Manusia dilihat dari kesesuaian dengan KD, Kesesuaian Kompetensi dengan KD, Kesesuaian Judul dengan kegiatan pratikum, kesesuaian tujuan dengan langkah kerja pratikum, dan kesesuaian kegiatan dengan tingkat kognitif siswa.

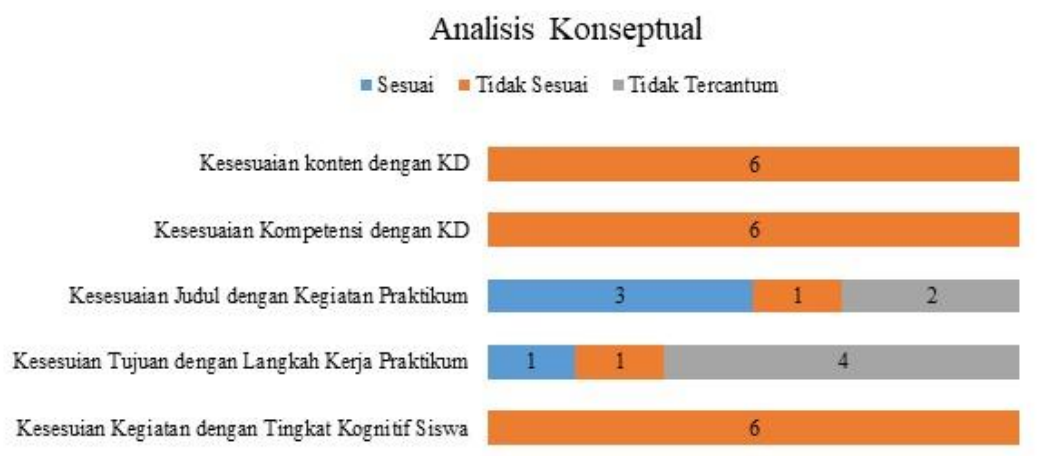

Gambar 2. Analisis Konseptual

Berdasarkan analisis konseptual yang ditunjukkan pada gambar 2. dari segi kesesuaian konten dengan kompetensi dasar seluruh Lembar Kerja Siswa (LKS) Sistem Pernapasan Manusia tidak didesain sesuai kurikulum pada Kurikulum 2013. 
Pada Kurikulum 2013 kompetensi dasar biologi materi Sistem Pernapasan Manusia di kelas XI MIPA terdapat pada KD 3.8 yang berbunyi "menganalisis hubungan antara struktur jaringan penyusun organ pada sistem pernapasan dalam kaitannya dengan bioproses dan gangguan fungsi yang dapat terjadi pada sistem pernapasan manusia". Salah satu tuntutan kompetensi dasar tersebut mengharuskan siswa untuk menganalisis hubungan antara struktur jaringan penyusun organ sistem pernapasan dalam kaitannya dengan bioproses (struktur dan fungsi paru-paru) dan gangguan fungsi yang dapat terjadi pada sistem pernapasan (penyakit pernapasan). Namun kegiatan praktikum pada semua sampel LKS yang dianalisis dan beredar di sekolah belum sesuai dengan Kompetensi Dasar yang harus dicapai. Kegiatan praktikum hanya membuktikan udara hasil pernapasan tanpa melibatkan udara yang digunakan dalam bernapas dan kaitannya dengan organ pernapasan. Selain itu terdapat beberapa LKS yang tidak mencantumkan judul dan tujuan sehingga kegiatan yang dilakukan siswa tidak jelas apa yang harus dicapainya.

Kegiatan praktikum ini lebih tepat diterapkan pada jenjang pendidikan SMP/MTs Kurikulum 2013 sesuai KD 3.8 yang berbunyi "memahami zat cair dan penerapannya dalam kehidupan sehari-hari untuk menjelaskan tekanan darah, difusi pada peristiwa pernapasan dan tekanan osmosis" yaitu siswa diminta untuk mengamati peristiwa pengikatan $\mathrm{O}_{2}$ dan pelepasan $\mathrm{CO}_{2}$ di paru-paru. Dengan demikian praktikum udara hasil pernapasan sesuai pada jenjang SMP/MTs kurikulum 2013 yang ditunjukan pada kekeruhan air kapur yang dapat ditafsirkan melalui reaksi kimia yang terjadi dalam proses peristiwa pernapasan.

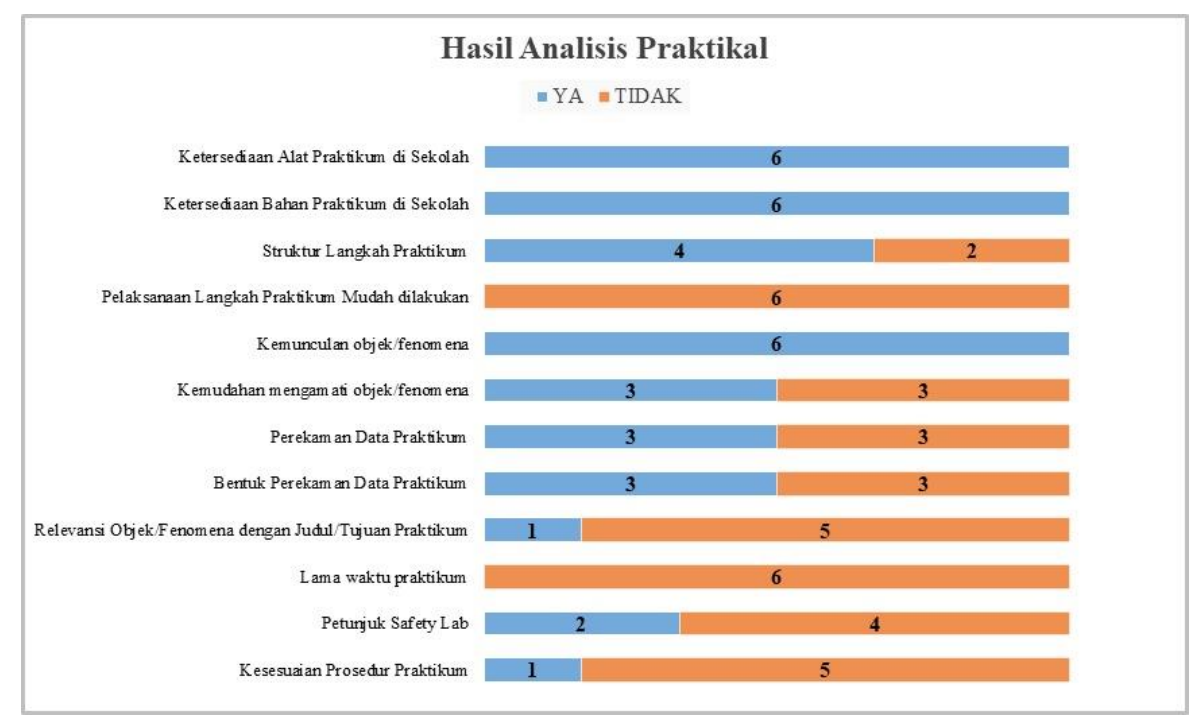

Gambar 3. Hasil Analisis Praktikal

Berdasarkan analisis praktikal yang ditunjukkan pada gambar 3. dalam segi alat dan bahan yang digunakan dalam kegiatan praktikum hasil udara pernapasan mudah ditemukan di sekolah maupun luar sekolah sehingga siswa dapat melakukan langkah kerja kegiatan praktikum tidak hanya di laboratorium saja. Alat dan bahan praktikum merupakan komponen utama yang sangat menunjang bagi kegiatan praktikum, karena tanpa keberadaan alat dan bahan kegiatan praktikum sulit untuk 
dijalankan (Wibowo, 2015). Kemudian, dalam segi langkah kerja beberapa terstruktur namun dalam eksekusinya terdapat kesulitan karena terdapat langkah kerja yang tidak jelas sehingga sulit dilakukan oleh siswa. Seperti adanya intruksi "sajikan data yang kamu dapat dalam bentuk tabel", namun tabel tidak disediakan dalam prosedur LKS. Lalu tidak ditentukan waktu lamanya pelaksanaan prosedur yang dilakukan ketika menunggu larutan air kapur sampai mengendap dan menuangkan air kapur yang jernih pada gelas hingga batas endapan yang berpengaruh terhadap kegiatan praktikum serta kesimpulan yang didapat. Dari segi perekaman data terdapat 3 LKS yang menyajikan perekaman data berupa tabel pengamatan sementara 3 LKS lainnya tidak disajikan. Selain itu, dalam segi fenomena seluruh LKS memunculkan fenomena dan mudah diamati berupa tingkat kekeruhan yang terjadi pada air kapur setelah ditiup, namun beberapa LKS tidak relevan dengan judul/tujuan praktikum. Hal ini disebabkan objek/fenomena yang terjadi tidak relevan serta tidak dicantumkannya judul/tujuan praktikum sehingga berpengaruh pada kesesuaian prosedur praktikum. Hanya terdapat 2 LKS yang terdapat petunjuk safety laboratorium sementara 4 LKS lainnya tidak mencantumkan. Safety laboratorium sangat penting bagi keselamatan saat pelaksanaan praktikum.

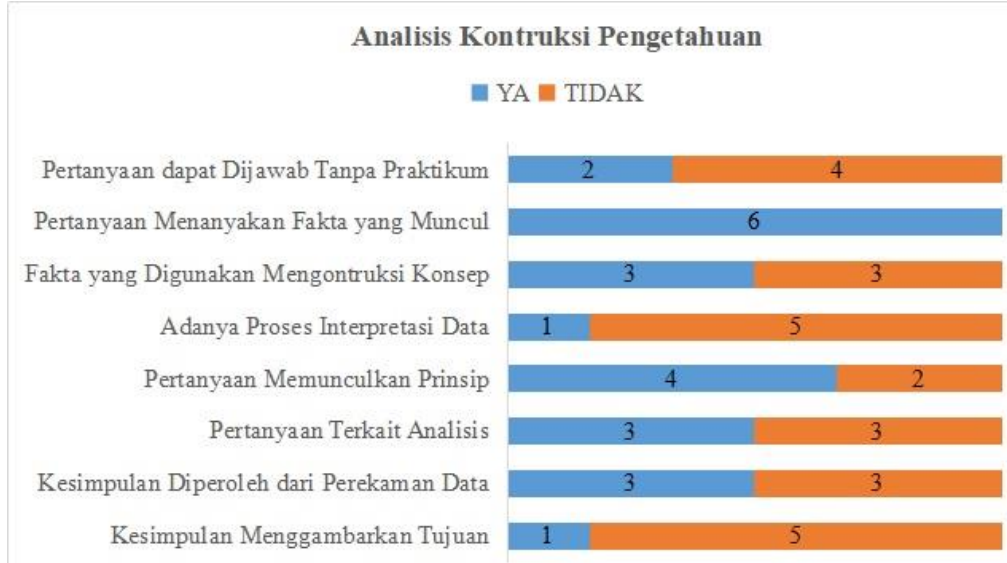

Gambar 4. Analisis Kontruksi Pengetahuan

Berdasarkan analisis kontruksi pengetahuan yang ditunjukkan pada gambar 4 . terdapat beberapa pertanyaan LKS yang dapat dijawab tanpa praktikum seperti "bagaimana keadaan air kapur dalam tabung reaksi $A, B$, dan $C$ sebelum dan sesudah ditiup" tetapi pada unjuk kreativitas disebutkan "kamu telah membuktikan bahwa udara pernapasan mengandung $\mathrm{CO}_{2}$ dan $\mathrm{H}_{2} \mathrm{O}$. Dalam membuktikan adanya $\mathrm{CO}_{2}$ dalam udara pernapasan, kamu menggunakan air kapur. Air kapur sebelum ditiup dalam keadaan bening. Setelah ditiup, air kapur menjadi keruh". Hal ini menunjukkan kegiatan praktikum tidak mampu mengkontruksi pengetahuan siswa sehingga dapat prosedur praktikum yang dilakukan akan menjadi sia-sia. Kemudian pertanyaan praktikum mengarahkan pada fakta yang muncul namun terdapat 3 LKS yang tidak menggunakan fakta untuk mengkontruksi konsep seperti perubahan warna air kapur yang ditetesi bromthymol blue dan fenolftalein tidak ada hubungannya dengan konsep sistem pernapasan tetapi hanya mengindikasi sifat asam-basa larutan. 
Pertanyaan terkait interpretasi data ditunjukkan pada perubahan dan reaksi kimia yang terjadi tetapi terdapat beberapa yang tidak menghubungkannya dengan interpretasi data yang disebabkan tidak adanya sajian perekaman data pada prosedur praktikum. Pertanyaan yang memunculkan suatu prinsip terdapat pada 4 LKS yaitu mengetahui penyebab terjadinya perubahan air kapur sebelum dan sesudah ditiup sedangkan 2 LKS lainnya tidak ada. Pertanyaan terkait analisis terdapat pada 3 LKS yaitu "bagaimana perubahan air kapur sebelum dan sesudah ditiup", "Apakah yang mengakibatkan terjadinya perubahan pada air kapur dalam tabung reaksi $A, B$, dan $C$ ". Terkait kesimpulan yang dibangun belum menggambarkan judul/tujuan praktikum sehingga dapat membuat siswa untuk mengkontruksi pengetahuannya. Hal ini disebabkan kegiatan praktikum lebih mengarah ke mengamati perubahan yang terjadi pada air kapur sementara pertanyaan belum semuanya mengarah pada kegiatan yang dilakukan dan tidak adanya perekaman data membuat siswa tidak dapat menginterpretasi serta menyesuaikannya dengan capaian yang diharapkan.

Hasil temuan tersebut sejalan dengan penelitian yang ditemukan oleh Wahidah, et.al., (2018) yang menyatakan bahwa seringkali pada Lembar Kerja Siswa (LKS) tujuan praktikum yang tidak jelas, terkadang tidak sesuai dengan peristiwa atau objek yang diamati. Kemudian, fakta yang diinginkan tidak muncul sesuai tujuan praktikum serta tidak sesuai teori, prinsip, maupun konsep terkait materi tersebut. Pada saat praktikum siswa tidak diintruksikan untuk mencatat fenomena apa saja yang ditemukan kebanyakan hanya mengamati. Hal ini jelas akan mempengaruhi penarikan kesimpulan yang dilakukan siswa karena kesimpulan harus sesuai tujuan praktikum. Selain itu berdasarkan hasil analisis kurikulum dan kegiatan LKS MGMP yang dilakukan oleh Suryawati, et.al., (2015) mengemukakan bahwa terdapat beberapa kegiatan yang kurang relevan. LKS masih berupa daftar pertanyaan yang cenderung tekstual, kurang melatih keterampilan berpikir dan sikap ilmah sehingga diperlukan pengembangan LKS yang dapat digunakan sebagai pedoman bagi guru dalam upaya pencapaian standar pendidik, standar kompetensi lulusan, standar proses dan penilaian.

\section{Instrumen Diagram Vee}

Berdasarkan analisis mengenai instrumen Diagram Vee yang diadaptasi Novak dan Gowin (1984) terdiri atas komponen pertanyaan fokus, objek/peristiwa, konsep/prinsip/teori, catatan transformasi dan klaim pengetahuan. Lembar Kerja Siswa (LKS) dari 6 sampel sudah mengikuti komponen Diagram Vee namun nilai untuk setiap skor komponen Diagram Vee belum mencapai skor maksimal sehingga belum ideal dalam menunjang kontruksi pengetahuan siswa. Berikut rekapitulasi skor LKS berdasarkan Diagram Vee dari 6 sampel LKS yang dianalisis dapat dilihat pada tabel 1. 
Tabel 1. Rekapitulasi Skor LKS Berdasarkan Diagram Vee

REKAPITULASI SKOR LKS BERDASARKAN DIAGRAM VEE

\begin{tabular}{|c|c|c|c|c|c|c|c|c|c|c|c|c|c|c|c|c|c|c|c|c|c|c|c|c|}
\hline \multirow{3}{*}{$\begin{array}{c}\text { Penerbit } \\
\text { LKS }\end{array}$} & \multicolumn{23}{|c|}{ Komponen Diagram Vee } & \multirow{3}{*}{$\begin{array}{c}\text { Total } \\
\text { Skor } \\
\text { Tiap } \\
\text { LKPD }\end{array}$} \\
\hline & \multicolumn{4}{|c|}{$\begin{array}{l}\text { Pertanyaan } \\
\text { Fokus }\end{array}$} & \multicolumn{4}{|c|}{$\begin{array}{c}\text { Objek/ } \\
\text { Peristiwa }\end{array}$} & \multicolumn{5}{|c|}{$\begin{array}{c}\text { Konsep/Prinsip/ } \\
\text { Teori }\end{array}$} & \multicolumn{5}{|c|}{$\begin{array}{c}\text { Catatan } \\
\text { Transformasi }\end{array}$} & \multicolumn{5}{|c|}{$\begin{array}{c}\text { Klaim } \\
\text { Pengetahuan }\end{array}$} & \\
\hline & 0 & 1 & 2 & 3 & 0 & 1 & 2 & 3 & 0 & 1 & 2 & 3 & 4 & 0 & 1 & 2 & 3 & 4 & 0 & 1 & 2 & 3 & 4 & \\
\hline LKS-01 & & & & $\sqrt{ }$ & & & & $\sqrt{ }$ & & & & $\sqrt{ }$ & & & & & & $\sqrt{ }$ & & & & $\sqrt{ }$ & & 16 \\
\hline LKS-02 & & & & $\sqrt{ }$ & & & & $\sqrt{ }$ & & & & $\sqrt{ }$ & & & & & & $\sqrt{ }$ & & & & $\sqrt{ }$ & & 16 \\
\hline LKS-03 & & & & $\sqrt{ }$ & & & & $\sqrt{ }$ & $\sqrt{ }$ & & & & & $\sqrt{ }$ & & & & & & $\sqrt{ }$ & & & & 7 \\
\hline LKS-04 & & & & $\sqrt{ }$ & & $\sqrt{ }$ & & & & & $\sqrt{ }$ & & & & & $\sqrt{ }$ & & & & & $\sqrt{ }$ & & & 10 \\
\hline LKS-05 & & $\sqrt{ }$ & & & & & & $\sqrt{ }$ & & $\sqrt{ }$ & & & & & & & & $\sqrt{ }$ & & & & $\sqrt{ }$ & & 12 \\
\hline LKS-06 & & & & $\sqrt{ }$ & & & & $\sqrt{ }$ & & $\sqrt{ }$ & & & & & & $\sqrt{ }$ & & & & & $\sqrt{ }$ & & & 11 \\
\hline Jumlah & \multicolumn{4}{|c|}{16} & \multicolumn{4}{|c|}{16} & \multicolumn{5}{|c|}{10} & \multicolumn{5}{|c|}{16} & \multicolumn{5}{|c|}{14} & 72 \\
\hline Rata-rata & \multicolumn{4}{|c|}{2,67} & \multicolumn{4}{|c|}{2,67} & \multicolumn{5}{|c|}{1.67} & \multicolumn{5}{|c|}{2,67} & \multicolumn{5}{|c|}{2,3} & \\
\hline
\end{tabular}

Berdasarkan tabel 1. menunjukkan rekapitulasi skor Diagram Vee dapat disimpulkan bahwa komponen pertanyaan fokus, objek/peristiwa dan catatan transformasi memiliki rata-rata 2,67 sedangkan klaim pengetahuan memiliki rata-rata 2,3 dan konsep/teori/prinsip memiliki skor rata-rata 1,67. Rata-rata pada komponen pertanyaan fokus, objek/peristiwa dan catatan transformasi skor rata-rata tinggi sedangkan konsep/teori/prinsip skor rata-rata rendah. Hasil analisis instrumen penskoran Diagram Vee menunjukkan bahwa komponen pertanyaan fokus, objek/peristiwa, konsep/teori/prinsip, catatan transformasi, dan klaim pengetahuan masih belum mencapai skor maksimal sehingga LKS Praktikum yang digunakan di sekolah belum menunjang komponen Diagram Vee dengan maksimal sehingga perlu ditingkatkan.

Pencatatan transformasi data dapat mengetahui sejauh mana siswa dapat mengkombinasikan teori, prinsip dan konsep yang mereka ketahui ke dalam rancangan catatan hasil pengamatannya (Novak \& Gowin, 1984) Dengan perintah mencatat atau mentransformasi data dapat membantu siswa dalam membentuk pengetahuannya dalam menjawab pertanyaan fokus sehingga kegiatan praktikum lebih bermakna (Solihat dalam Wahidah et.al., 2018).

\section{Rekonstruksi Kegiatan Praktikum LKS Sistem Pernapasan Manusia}

Menurut Millar (2004) efektivitas suatu kerja praktikum dapat diukur dari segi (1) prosedur kegiatan, yakni berkaitan dengan apa yang dikerjakan siswa dan (2) hasil kerja praktikum, berkaitan dengan apa yang dipelajari siswa. Efektivitas langkah kerja yang dimaksud merupakan terlaksananya langkah/prosedur kerja dalam desain kegiatan laboratorium dan juga menghasilkan data/fakta yang diharapkan. Berdasarkan analisis peneliti mengenai kegiatan praktikum membuktikan udara hasil pernapasan dan uji coba yang telah dilakukan bahwa kegiatan praktikum hanya membuktikan output dari hasil pernapasan yaitu $\mathrm{CO}_{2}$ sedangkan hakikat dari proses pernapasan perlu adanya input yang digunakan untuk bernapas. Maka peneliti mencoba merekonstruksi dengan mengembangkan kegiatan praktikum tersebut . 


\section{Membuktikan Udara $\mathrm{O}_{2}$ dan $\mathrm{CO}_{2}$ dalam Pernapasan}

\section{A. Tujuan Praktikum}

1. Mengetahui organ-organ yang berperan dalam sistem pernapasan

2. Memahami mekanisme proses inspirasi dan ekspirasi

3. Membuktikan adanya $\mathrm{CO}_{2}$ sebagai hasil pernapasan

4. Membuktikan adanya $\mathrm{O}_{2}$ sebagai udara yang digunakan dalam proses bernapas

\section{B. Alat dan Bahan}
1. Tabung Erlenmeyer/Gelas
6. Lilin
2. Sendok
7. Korek Api
3. Sedotan
8. Spidol
4. Air Kapur (gamping) direndam sehari semalam
9. Buku Kerja
5. Stopwatch
10. Alat Tulis

\section{Cara Kerja}

\section{Udara Hasil Pernapasan}

1. Siapkan 3 buah Erlenmeyer yang bersih

2. Berilah label A, B, dan C pada masing-masing Erlenmeyer menggunakan spidol

3. Masukkan air suling pada Erlenmeyer A kemudian hiruplah udara melalui hidung, tahan beberapa detik dan hembuskan udara melalui mulut kedalam Erlenmeyer A tiuplah menggunakan sedotan. Amati perubahan apa yang terjadi!

4. Masukkan air kapur pada Erlenmeyer B kemudian aduklah mengunakan sendok. Amati perubahan apa yang terjadi!

5. Masukkan air kapur pada Erlenmeyer $\mathrm{C}$ kemudian hiruplah udara melalui hidung, tahan beberapa detik dan hembuskan udara melalui mulut kedalam Erlenmeyer $\mathrm{C}$ tiuplah menggunakan sedotan. Amati perubahan apa yang terjadi!

6. Setelah mengamati perubahan yang terjadi, catatlah hasil pengamatan Anda kedalam bentuk tabel seperti berikut

\begin{tabular}{|l|c|c|c|c|}
\hline \multirow{2}{*}{ No } & \multirow{2}{*}{ Perlakuan } & \multicolumn{2}{|c|}{ Hasil Pengamatan } & \multirow{2}{*}{ Keterangan } \\
\cline { 3 - 4 } & & Sebelum & Sesudah & \\
\hline 1 & Tabung Erlenmeyer A & & & \\
\hline 2 & Tabung Erlenmeyer B & & & \\
\hline 3 & Tabung Erlenmeyer C & & & \\
\hline
\end{tabular}

Udara yang Digunakan dalam Proses Benapas

1. Siapkan 2 buah lilin dan 2 buah Erlenmeyer

2. Nyalakan kedua lilin menggunakan korek api 
3. Lilin yang pertama ditutup dengan Erlenmeyer yang telah diberikan udara dari mulut (dengan cara ditiup), amati perubahan yang terjadi dan catat perubahan yang terjadi hitung waktunya menggunakan stopwatch!

4. Lilin yang kedua ditutup dengan Erlenmeyer yang terbuka yang berisi udara (tanpa ditiup) amati perubahan yang terjadi dan catat perubahan yang terjadi hitung waktunya menggunakan stopwatch!

5. Catatlah hasil pengamatan anda kedalam tabel berikut

\begin{tabular}{|l|l|l|}
\hline No & Perlakuan & Waktu Padam \\
\hline 1 & Lilin Pertama & \\
\hline 2 & Lilin Kedua & \\
\hline
\end{tabular}

6. Buatlah laporan praktikum berdasarkan hasil pengamatan masing-masing praktikum dan persentasikan di depan kelas menggunakan bahasa yang sopan dan mudah dimengerti

\section{Pertanyaan dan Diskusi}

1. Organ apa saja yang berperan ketika menghirup udara dan menghembuskan udara pernapasan ke dalam Erlenmeyer A dan C?

2. Bagaimana mekanisme yang terjadi ketika menghirup udara dan menghembuskan udara pernapasan ke dalam Erlenmeyer $\mathrm{A}$ dan $\mathrm{C}$ ?

3. Bagaimana perubahan yang terjadi pada air suling dalam Erlenmeyer A sebelum dan sesudah ditiup menggunakan sedotan? Jelaskan persamaan reaksi yang terjadi!

4. Bagaimana perubahan yang terjadi pada air kapur dalam Erlenmeyer B sebelum dan sesudah diaduk menggunakan sendok? Jelaskan persamaan reaksi yang terjadi!

5. Bagaimana perubahan yang terjadi pada air kapur dalam Erlenmeyer $\mathrm{C}$ sebelum dan sesudah ditiup menggunakan sedotan? Jelaskan persamaan reaksi yang terjadi!

6. Bagaimana perbedaan tingkat kekeruhan yang terjadi pada Erlenmeyer B dan Erlenmeyer C? Jelaskan mengapa terjadi perbedaan tingkat kekeruhan!

7. Bagaimana cara menunjukkan bahwa udara yang dihasilkan dari pernapasan berupa $\mathrm{CO}_{2}$ berdasarkan tingkat kekeruhan yang terjadi pada Erlenmeyer $\mathrm{C}$ ?

8. Mengapa lilin A dan lilin B bisa padam?

9. Berapa perbedaan lama waktu padam ketika lilin menyala pada lilin A dan lilin $B$ ? Jelaskan mengapa terjadi perbedaan lama waktu padam ketika lilin menyala!

10. Berdasarkan pengamatan ketika lilin menyala dan padam, bagaimana kaitannya dengan $\mathrm{O}_{2}$ yang masuk kedalam tubuh lebih banyak dibandingkan $\mathrm{CO}_{2}$ ?

11. Apa kesimpulan Anda dari kegiatan praktikum ini? 


\section{DISKUSI}

Berdasarkan hasil analisis peneliti bahwa kegiatan praktikum pada 6 sampel LKS belum sesuai tuntutan kompetensi dasar pada Kurikulum 2013 secara konseptual, praktikal, dan kontruksi pengetahuan siswa. Maka dari itu perlu adanya rekonstruksi kegiatan praktikum LKS Sistem Pernapasan Manusia yang relevan dengan Kompetensi Dasar Kurikulum 2013. Sejalan dengan pendapat Suryaningsih (2017) proses pengajaran biologi memerlukan kegiatan praktikum untuk membekali siswa dalam mencapai kompetensi yang diharapkan kurikulum. Beberapa permasalahan yang ditemukan di sekolah LKS yang digunakan tidak sesuai dengan urutan indikator pencapaian komptensi dan indikator yang dibuat guru (Ardhiantari, et.al., 2015). LKS yang digunakan siswa belum memfasilitasi untuk merekontruksi sendiri pengetahunnya (Fannie dan Rohati, 2014).

Kerja praktek merupakan aktivitas mengajar dan belajar yang melibatkan siswa dalam observasi, manipulasi objek dan bahan-bahan nyata (Millar, 2004). Kegiatan praktek hendaknya memberikan kesempatan kepada siswa untuk secara aktif memperoleh data atas objek/event yang diobservasi sehingga memungkinkan adanya kontruksi pengetahuan. Kontruksi pengetahuan dimulai dari observasi terhadap objek atau peristiwa. Karakteristik objek/event sebagai fakta observasi biasanya dinyatakan data kualitatif atau kuantitatif. Proses kontruksi pengetahuan dimulai dengan mencoba mencari hubungan fakta yang ada dengan pengetahuan yang sudah dimiliki (Supriatno, 2018).

\section{KESIMPULAN}

Hasil analisis kegiatan praktikum LKS pada materi Sistem Pernapasan Manusia masih ditemukan permasalahan dalam hal analisis 1) konseptual, belum sesuai dengan tuntutan Kompetensi Dasar kurikulum 2) praktikal, judul/tujuan belum sesuai langkah kerja dan sulit dieksekusi serta tidak relevan dengan objek/fenomena yang muncul 3) kontruksi pengetahuan, pertanyaan belum mengarahkan pada fakta yang muncul, tidak dihungungkan dengan interpretasi data serta kesimpulan yang dibangun belum menggambarkan judul/tujuan praktikum. Berdasarkan hasil analisis instrumen penskoran Diagram Vee menunjukkan bahwa komponen pertanyaan fokus, objek/peristiwa, konsep/teori/prinsip, catatan transformasi, dan klaim pengetahuan masih belum mencapai skor maksimal sehingga LKS Praktikum yang beredar belum menunjang komponen Diagram Vee dengan maksimal sehingga perlu ditingkatkan. Dari hasil analisis peneliti diketahui praktikum membuktikan udara hasil pernapasan, hanya membuktikan output dari pernapasan yaitu $\mathrm{CO}_{2}$ sedangkan hakikat dari proses pernapasan perlu adanya input yang digunakan untuk bernapas.

\section{DAFTAR PUSTAKA}

Asrianengsi S., Irwandi., \& Kasmiruddin. (2018). Pengembangan Modul Praktikum Biologi Berbasis Problem Based Learning (PBL) untuk Meningkatkan 
Kemampuan Berpikir Kritis Peserta Didik SMA Negeri Kota Bengkulu. Prosiding Seminar Nasional Pendidikan Biologi, 221-228.

Ardhiantri, W., Fadiawati, N., \& Kadaritna N. (2015). Pengembangan LKS Berbasis Keterampilan Proses Sains Pada Materi Hukum-Hukum Dasar Kimia. Jurnal Pendidikan dan Pembelajaran Kimia, 1 (4), 312-323.

Carin, AA. (1997). Teaching Modern Science $7^{\text {th }}$ Edition. New Jersey: Merril Publishing Company.

Fannie, RD., \& Rohati. (2014). Pengembangan Lembar Kerja Siswa (LKS) Berbasis POE (Predict, Observe, Explain) Pada Materi Program Linier Kelas XII SMA. Saintmatika, 8 (1), 96-109.

Huzaifah S, Madang K, \& Zen D. (2017). Penerapan Diagram Vee untuk Meningkatkan Hasil Belajar Mahasiswa Program Studi Pendidikan Biologi pada Mata Kuliah Metodologi Penelitian. Prosiding Seminar Nasional Pendidikan IPA, 610-620.

Millar, R. (2004). The Role of Practical Work in the Teaching and Learning of Science. Washington DC: National Academic of Science.

Novak \& Gowin. (1984). Learning How to Learn. New York: Cambidge University Press.

Sudarisman, S. (2015). Memahami Hakikat dan Karakteristik Pembelajaran Biologi dalam Menjawab Tantangan Abad 21 serta Optimalisasi Implementasi Kurikulum 2013. Jurnal Florea, 2 (1), 29-35.

Supriatno, B. (2013). "Pengembangan Program Perkuliahan Pengembangan Praktikum Biologi Sekolah Berbasis ANCORB untuk Mengembangkan Kemampuan Merancang dan Mengembangkan Desain Kegiatan Laboratorium". Disertasi. Jurusan Pendidikan IImu Pengetahuan Alam. UPI: Tidak diterbitkan.

Supriatno, B. (2018). Praktikum untuk Membangun Kompetensi. Proceeding Biologi Education Conference, 15 (1), 1-18.

Suryaningsih, Y. (2017). Pembelajaran Berbasis Praktikum sebagai Sarana Siswa untuk Berlatih Menerapkan Keterampilan Proses Sains dalam Materi Biologi. Jurnal Bio Educatio, 2 (2), 49-57. 